\title{
Compared water deficit response of two Populus $x$ euramericana clones, Luisa Avanzo and Dorskamp
}

\author{
Franck Brignolas*, Cécile Thierry, Gilles Guerrier and Éric Boudouresque \\ Laboratoire Biologie des Ligneux, EA 1207, Université d'Orléans, BP. 6759, F-45067 Orléans Cedex 02, France
}

(Received 22 June 1999; accepted 31 August 1999)

\begin{abstract}
The drought response of two Populus x euramericana clones cv Dorskamp and Luisa Avanzo was investigated using potted cuttings growing in a greenhouse. The cv Dorskamp clone is known to be more tolerant than Luisa Avanzo under field conditions. Watering was withheld and several parameters followed during the onset of drought. The relation between predawn leaf water potential $\left(\Psi_{w p}\right)$ and soil water content differed between clones: (i) $\Psi_{w p}$ tended to decline when soil water content decreased below a threshold of $0.11 \mathrm{v} / \mathrm{v}$ and $0.13 \mathrm{v} / \mathrm{v}$ for Dorskamp and Luisa Avanzo, respectively; and (ii) $\Psi_{\mathrm{wp}}$ of stressed cuttings reached -3.5 MPa and -2.5 MPa for Dorskamp and Luisa Avanzo, respectively. Under well watered conditions, Luisa Avanzo had greater relative rates of increase in number of leaves and leaf growth than in Dorskamp. In response to water stress, the relative rates of increase in number of leaves and leaf growth did not significantly differ between the two clones for similar $\Psi_{w p}$ values. Thus, the growth advantage of Luisa Avanzo observed under control condition appeared counterbalanced by its higher susceptibility to water stress. Our results corroborated field observations on mature trees.
\end{abstract}

drought / leaf area / Populus $x$ euramericana / predawn water potential / soil water content

Résumé - Comparaison de la réponse à un arrêt d'arrosage de deux clones de Populus $x$ euramericana, Luisa Avanzo et Dorskamp. La réponse à un stress hydrique de deux clones de Populus x euramericana cv Dorskamp et Luisa Avanzo a été étudiée en serre à partir de boutures en pots. Le stress a été initié par arrêt d'arrosage et différents paramètres ont été suivis. La relation entre le potentiel de base foliaire $\left(\Psi_{\mathrm{wp}}\right)$ et la teneur en eau du sol diffère entre clones : (i) $\Psi_{\mathrm{wp}}$ tend à diminuer lorsque la teneur en eau du sol atteint le seuil de $0.11 \mathrm{v} / \mathrm{v}$ pour Dorskamp, alors qu'il diminue à partir de $0,13 \mathrm{v} / \mathrm{v}$ pour Luisa Avanzo ; (ii) $\Psi_{\text {wp }}$ des plants stressés atteint réversiblement -3,5 MPa pour Dorskamp et seulement -2,5 MPa pour Luisa Avanzo. En condition témoin, les taux d'apparition et de croissance des feuilles de Luisa Avanzo sont supérieurs à ceux de Dorskamp. En réponse au stress, ces paramètres ne diffèrent plus entre clones pour des $\Psi_{\text {wp }}$ comparables. L'avantage de croissance observé chez Luisa Avanzo en condition témoin n'apparaît plus en réponse au stress ; la plus grande sensibilité de ce clone au stress hydrique corrobore donc les observations réalisées en conditions naturelles.

stress hydrique / surface foliaire / Populus $\times$ euramericana / potentiel foliaire de base / teneur en eau du sol

\section{INTRODUCTION}

Fast growing trees, such as poplar, raised in shortrotation intensive cultures represent an alternative use for agricultural land [4, 21, 22]. However, drought peri- ods are responsible for both a decrease in poplar biomass production and an increase in sensitivity to some pathogens [18, 21].

Mechanisms involved in the adaptive response of the whole plant to water stress tend to increase plant water

* Correspondence and reprints

Tel. 332384948 02; Fax. 332384170 93; e-mail: franck.brignolas@univ-orleans.fr 
use efficiency [15] and to maintain photosynthetic activity [8]. Because of the high degree of variation in drought tolerance among Populus genotypes [7, 10, 11, 13, 19, 24], a number of important physiological and morphological traits are receiving attention including: stomatal closure [5, 13, 16], osmotic adjustment [10], leaf area reduction, leaf abscission, and root/shoot ratio increase $[7,14,16,24]$. Stomatal closure is an essential component of the response to drought, and results in a reduction of water loss by transpiration [5]. Early stomatal closure in response to soil drying can avoid leaf abscission [16] and catastrophic cavitation [5, 13]. Osmotic adjustment, as a result of solute accumulation, can enable plants to survive through, and recover from short dry periods $[3,17]$. For several deciduous tree species, a greater capacity for osmotic adjustment seems to be associated with greater dehydration tolerance [1]. However, differences in drought resistance between some poplar clones could not be explained by differences in osmotic adjustment [11]. Leaf area reduction, including leaf abscission and reduced leaf growth, resulting in an increase in root/shoot ratio, are also adaptive response to drought $[7,14,16,24]$. These responses are adaptive to both short-term intensive drought and longterm site water balance.

While whole plant responses to water stress have been well studied in poplar, cellular mechanisms still remain unclear. Comparison of biochemical and molecular responses between a drought-tolerant and a drought-sensitive clone may help to characterise relevant differences in the pattern of drought response, and then could provide early markers associated with water stress resistance.

In order to study drought tolerance at the cellular level, we have selected two Populus $x$ euramericana clones (Luisa Avanzo and Dorskamp) originating from the Aigeiros section. Based on field observations, these two clones differed in drought tolerance, but originated from crossings of the same parental species. The following are limiting cultural conditions for Luisa Avanzo: high clay levels, high density, flooding or lack of water and lack of nutrients. In contrast, the Dorskamp clone is more plastic and less water-demanding [21, 23].

The first step in developing model clones for biochemical and molecular studies is the controlled validation of the above mentioned cultural observations. The purpose of this study was to test the drought behaviour of both clones by measuring several parameters on control and drought-stressed cuttings grown under greenhouse conditions. The measured parameters included: soil water content, predawn leaf water potential [7, 24], number of leaves [7, 14], and leaf area [2, 6, 12]. For the latter, a basic, but not-destructive, allometric relationship had to be developed between leaf dimensions (length, width) and leaf area $[6,9,25]$.

\section{MATERIALS AND METHODS}

Two-month-old 20-cm woody stem cuttings, from 1year-old cut-back stems of two Populus $x$ euramericana (Dode) Guinier (P. deltoides (Bartr.) Marsh. $x$ P. nigra L.) cv "Dorskamp" [male] and "Luisa Avanzo" [female] clones, were used in all experiments.

\subsection{Establishment and validation of basic allometric relationships between leaf dimensions and leaf area}

In October 1997, 40 leaves of Dorskamp and 32 leaves of Luisa Avanzo were collected from 4 woodystem cuttings of each clone. Leaf length (from lamina tip to petiole insertion along the main vein), maximum width (perpendicularly to the main vein) and leaf area were measured. Leaf area was determined using an automatic image analyzer (Biocom Imagenia 5000 2.0).

To establish the basic relations between leaf dimensions and leaf area for each clone, two models were tested: a linear model $\left(A_{\mathrm{m}}=a X+b\right)$ and a logarithmic one $\left(\log A_{\mathrm{m}}=a \log X+b\right)$ i.e. $\left(A_{\mathrm{m}}=10^{a \log X+b}\right)$, where $A_{\mathrm{m}}$ is the measured leaf area and $X$ the leaf length or leaf width. These formulae were validated at both leaf and cutting levels by measuring leaf area $\left(A_{\mathrm{m}}\right)$ and cutting leaf area $\left(C_{\mathrm{m}}=\Sigma A_{\mathrm{m}}\right)$ on 5 other heterogeneous cuttings of each clone (in a range of one to two-months-old cuttings, with 5 to 16 leaves each). Overall leaves of cuttings, 52 for Dorskamp and 58 for Luisa Avanzo, were measured. The width of each leaf was manually measured and the selected relationships were applied for each clone to estimate leaf area $\left(A_{\mathrm{e}}\right)$ and total leaf area per cutting $\left(C_{\mathrm{e}}=\Sigma A_{\mathrm{e}}\right)$. The correlation between calculated $\left(A_{\mathrm{m}}, C_{\mathrm{m}}\right)$ and estimated $\left(A_{\mathrm{e}}, C_{\mathrm{e}}\right)$ parameters were checked by linear regression (Pearson's coefficient), and tested with the Student's distribution $(p \leq 0.05)$ using SPSS software.

\subsection{Stress experiment}

In February 1998, 130 twenty cm woody stem cuttings of each clone were planted into $300 \mathrm{ml}$ plastic pots until rooting occurred. One month later, each cutting was repotted in 11 pots containing sand/peat moss/clay $(50 / 45 / 5, \mathrm{v} / \mathrm{v} / \mathrm{v}, \mathrm{pH} 7)$ together with dolomite $\left(3 \mathrm{~kg} / \mathrm{m}^{3}\right)$, and chemical fertilisers N-P-K (15-9-15) to a total concentration of $2 \mathrm{~kg} / \mathrm{m}^{3}$. All cuttings were regularly 
watered to field capacity until April, the start of the experiment.

Drought stress experiment was conducted in a greenhouse exposed to natural daylight. On April 6, 1998 (d 96 of the year) water stress was induced by withholding water from 100 cuttings of each clone. The remaining cuttings were regularly watered to field capacity and constituted the controls. For each clone, 5 drought stressed cuttings and 3 or 5 controls were collected weekly for estimating the following parameters:

1- Predawn leaf water potential $\left(\Psi_{\mathrm{wp}}\right)$ was measured with a Scholander pressure chamber on a fully expanded leaf [20]. When $\Psi_{w p}$ of stressed cuttings became significantly lower than that of controls, 5 other stressed cuttings per clone, chosen at random, were rewatered, and their $\Psi_{\text {wp }}$ was estimated c.a. one week later. The experiment was stopped when $\Psi_{\text {wp }}$ of rewatered cuttings did not return to a control value.

2- Soil water content was measured from a calibrated volume of homogeneous soil $\left(345 \mathrm{~cm}^{3}\right)$. This soil was weighted and placed at $100{ }^{\circ} \mathrm{C}$ for 24 hours before measure of dry weight. Results were expressed in grams of water per $\mathrm{cm}^{3}$ soil $(=\mathrm{v} / \mathrm{v})$.

From April 6, 1998, the number of leaves and each leaf's width were measured fortnightly for each remaining cutting. Results were expressed in two ways: (i) at each date of measure, the total number of leaves and the total foliar area of each cutting were expressed as the percent of their initial value measured at day 96; (ii) for each level of water stress ( $\Psi_{\text {wp }}$ values), the relative rates of increase in number of leaves $\left(\right.$ day $^{-1}$ ) and leaf growth $\left(\right.$ day $\left.^{-1}\right)$ of each cutting were calculated using the following equation: $\left[\left(X_{2}-X_{1}\right) /\left(t_{2}-t_{1}\right)\right]$, where $X_{1}$ and $X_{2}$ are the number of leaves or leaf area at times $t_{1}$ and $t_{2}$, respectively. All leaves were taken into account in these calculations over the experiment, including the fallen leaves. These parameters were also estimated for weekly collected cuttings. Means ( \pm standard error) were com- pared by variance analysis (SPSS software), and were considered significantly different when $P \leq 0.05$.

\section{RESULTS AND DISCUSSION}

\subsection{Relation between leaf dimensions and leaf area for each clone}

Leaf sizes in the Dorskamp cuttings ranged from 19 to $63 \mathrm{~mm}$ wide, 27 to $67 \mathrm{~mm}$ long, and from 3.5 to $26 \mathrm{~cm}^{2}$ in area. The respective dimensions of Luisa Avanzo leaves were $23-62 \mathrm{~mm}, 32-58 \mathrm{~mm}$, and $4.5-24 \mathrm{~cm}^{2}$. The logarithmic and linear equations were developed between leaf area $\left(A_{\mathrm{m}}\right)$ and either leaf length or width; both equations were highly significant $(P \leq 0.01)$. Best fits were obtained with the width parameter $(w)$ particularly for Dorskamp (table I). The linear model had a negative intercept which was significantly different from zero. Because such intercept values could lead to negative leaf areas for small leaves, the logarithmic model was chosen for estimating leaf area at both the leaf and cutting levels. This model was then validated on other cuttings by linear regression at leaf $\left(A_{\mathrm{e}}=a A_{\mathrm{m}}+b\right)$ and cutting levels $\left(C_{\mathrm{e}}=a C_{\mathrm{m}}+b\right)$. According to the significant results (table II), the equations retained for further estimation of cutting leaf area were: $A_{\mathrm{e}}=10^{1.81 \log w}$ and $A_{\mathrm{e}}=10^{1.73 \log w}$ for Luisa Avanzo and Dorskamp, respectively.

\subsection{Stress experiment}

Woody stem cuttings of both clones ( $n=130$ cuttings by clone) were prepared exactly at the same time; however, at the beginning of the experiment (April 6, $1998=$ d 96), Luisa Avanzo cuttings exhibited a smaller number of leaves and total leaf area than Dorskamp $(8.5 \pm 0.3$ and $67.9 \mathrm{~cm}^{2} \pm 2.6$ vs. $11.5 \pm 0.3$ and $84.4 \mathrm{~cm}^{2} \pm 3.1$,

Table I. Establishment of a mathematical function between measured leaf area and measured leaf width or measured leaf length. Two models were tested: model 1 , linear function $\left(A_{\mathrm{m}}=a X+b\right)$; model 2 , logarithmic function $\left(\log A_{\mathrm{m}}=a \log X+b\right)$. $A_{\mathrm{m}}=$ measured leaf area; $X=$ measured leaf width $(w)$, or measured leaf length $(l) ; r=$ Pearson's coefficient; $(* *) \stackrel{m}{=}$ Significant correlation at $P$ $\leq 0.01 . n=$ number of data points used for linear regression.

\begin{tabular}{|c|c|c|c|c|c|c|c|}
\hline & & \multicolumn{3}{|c|}{$\begin{array}{l}\text { model } 1 \\
\text { regression parameters }\end{array}$} & \multicolumn{3}{|c|}{$\begin{array}{l}\text { model } 2 \\
\text { regression parameters }\end{array}$} \\
\hline & & $a$ & $b$ & $r$ & $a$ & b & $r$ \\
\hline \multirow{4}{*}{$\begin{array}{l}\text { Dorskamp } \\
(n=40) \\
\text { Luisa Avanzo } \\
(n=32)\end{array}$} & $f(w)$ & 4.97 & -8 & $0.96(* *)$ & 1.73 & 0 & $0.97(* *)$ \\
\hline & $f(l)$ & 4.21 & -7.6 & $0.91(* *)$ & 0.833 & 0.04 & $0.91(* *)$ \\
\hline & $f(w)$ & 5.05 & -7.5 & $0.97(* *)$ & 1.81 & $00.97(* *)$ & \\
\hline & $f(l)$ & 6.15 & -5.4 & $0.96(* *)$ & 2.36 & 0 & $0.96(* *)$ \\
\hline
\end{tabular}


Table II. Linear regression parameters between measured areas using an image analyser, and calculated areas using the logarithmic model at both leaf and cutting levels $\left(A_{\mathrm{e}}=a A_{\mathrm{m}}+b\right.$ and $\left.C_{\mathrm{e}}=a C_{\mathrm{m}}+b\right)$. Regression parameters: slope $(s)$, intercept $(i)$, Pearson's coefficient $(r)$. Significant correlation are indicated by $(*)(P \leq 0.05) ; C_{\mathrm{e}}=$ estimated leaf area per cutting: i.e. sum of individual estimated leaf area of all the cutting leaves $\left(C_{\mathrm{e}}=\Sigma A_{\mathrm{e}}\right) ; C_{\mathrm{m}}=$ measured leaf area per cutting; $A_{\mathrm{e}}=$ estimate leaf area; $A_{\mathrm{m}}=$ measured leaf area and $n=$ number of data points used for linear regression.

\begin{tabular}{llccc}
\hline & & \multicolumn{3}{c}{ Logarithmic model } \\
& & $s$ regression parameters \\
& & & $i$ & $r$ \\
\hline $\begin{array}{l}\text { Dorskamp } \\
(n=52)\end{array}$ & per leaf & 0.913 & 0 & $0.97^{*}$ \\
& per cutting & 0.986 & 0 & $0.96^{*}$ \\
Luisa Avanzo & per leaf & 1.04 & 0 & $0.98^{*}$ \\
$(n=58)$ & per cutting & 1.09 & 0 & $0.95^{*}$ \\
\hline
\end{tabular}

respectively). The $24.3 \%$ difference in leaf area likely affected the rate of water use and, therefore, drought development.

\subsubsection{Soil water content and predawn leaf water potential}

Soil water content and predawn leaf water potential $\left(\Psi_{\text {wp }}\right)$ of control cuttings, which were watered weekly to field capacity, remained above $0.14 \mathrm{v} / \mathrm{v}$ and $-1 \mathrm{MPa}$, respectively (figure 1). These parameters did not significantly differ between both control clones throughout the experiment.

Soil water content of stressed cuttings, which gradually decreased during the time course of the experiment, became significantly lower than in controls, 14 and 21 days after withholding irrigation for Dorskamp and Luisa Avanzo, respectively. From day 14 to day 28, the decrease in soil water content was faster and greater for Dorskamp than for Luisa Avanzo (data not shown). Hence, during this period, it was assumed that Dorskamp was exposed to a greater stress than Luisa Avanzo. These differences between clones resulted from the greater transpiration of Dorskamp cuttings due to the larger initial leaf development. $\Psi_{\text {wp }}$ of Dorskamp and Luisa Avanzo stressed cuttings tended to decline when soil water contents were less than $0.11 \mathrm{v} / \mathrm{v}$ and $0.13 \mathrm{v} / \mathrm{v}$, respectively (figure 1). These values can be considered as a threshold for stress initiation [24], because the best fit linear regressions (one for the steep decline at low soil water content and one for the asymptotic plateau at high soil water content) intersected at these values. Despite the initial and more rapid decrease in soil water content

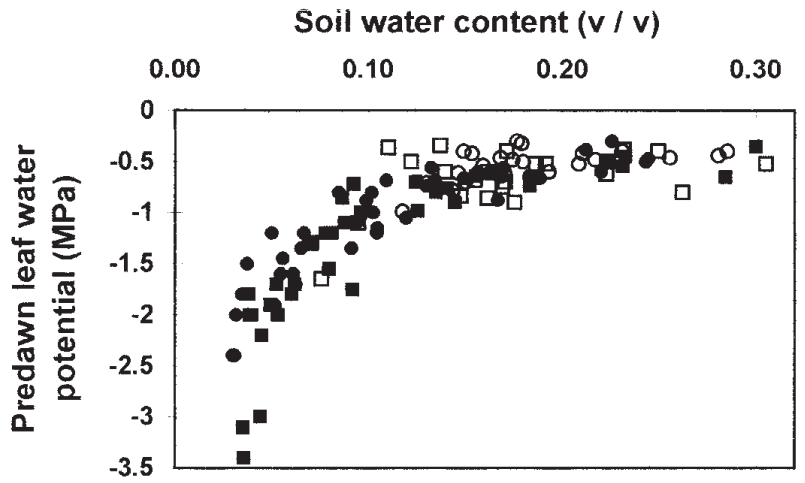

Figure 1. Predawn leaf water potentials $\left(\Psi_{\mathrm{wp}}\right)$ and soil water contents in control $(\bigcirc \square)$ and stressed cuttings $(\mathbf{W} / \mathbf{})$ of clones Dorskamp ( $\square / \square)$ and Luisa Avanzo (○/๑).

noted for Dorskamp, the threshold of stress initiation was lower for Dorskamp than for Luisa Avanzo. Differences between clones, in the relation [soil water content $\left./ \Psi_{\mathrm{wp}}\right]$, could be explained by differences in the depth of rooting or in the distribution of soil water [8]. In addition, $\Psi_{\mathrm{wp}}$ of stressed cuttings could reversibly reach $-3.5 \mathrm{MPa}$ and $-2.5 \mathrm{MPa}$ for Dorskamp and Luisa Avanzo, respectively. This last result demonstrated that Dorskamp can tolerate more negative water potentials than Luisa Avanzo.

\subsubsection{Growth of the two hybrid poplar clones}

Under well watered conditions, the total number of leaves reached c.a. $270 \%$ and $370 \%$ of initial values for Dorskamp and Luisa Avanzo, respectively (figures $2 \mathrm{~A}$ and $B$ ). Similar differences were also observed for the increase in total leaf area: c.a. $550 \%$ and $800 \%$, respectively (figures $2 C$ and $D$ ). These results were corroborated by significantly greater relative rates of increase in number of leaves and leaf growth in Luisa Avanzo than in Dorskamp (figures $3 A$ and $B$ ). These growth differences detected between clones in greenhouse conditions showed that Luisa Avanzo is a faster growing clone than Dorskamp. Similar differences were also observed in large-scale plantations, on a trunk circumference basis [23].

In response to water stress, the total number of leaves reached c.a. $200 \%$ and $280 \%$ of initial values for Dorskamp and Luisa Avanzo, respectively (figures $2 \mathrm{~A}$ and $B$ ). Moreover, both in the case of Dorskamp and Luisa Avanzo, the total leaf area reached c.a. $350 \%$ of their initial values (figures $2 C$ and $D$ ). For similar $\Psi_{\mathrm{wp}}$ 

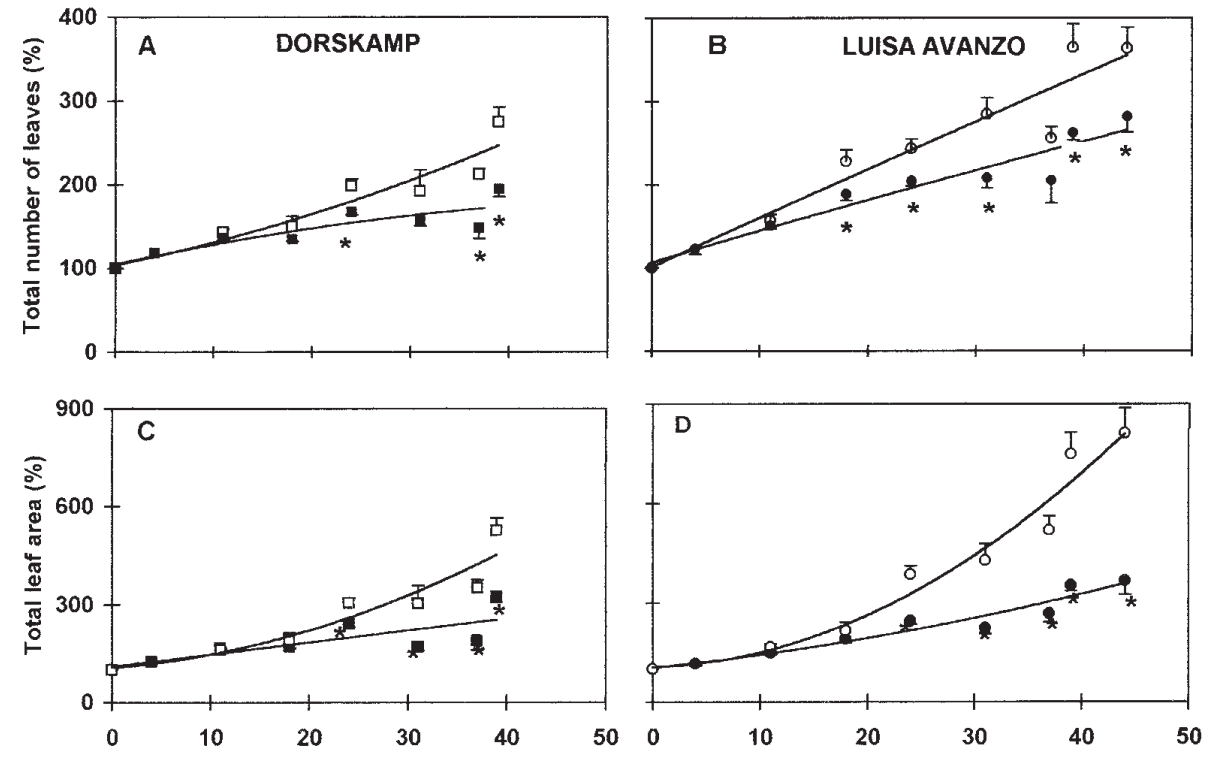

Days after withholding water
Figure 2. Time course of total number of leaves (A and $\mathrm{B}$ ) and total leaf area $(\mathrm{C}$ and $\mathrm{D})$ in control $(\square / \bigcirc)$ and stressed cuttings $(\square / 0)$ of Dorskamp ( $\square / \mathbf{\square})$ and Luisa Avanzo $(\bigcirc / 0)$. Means ( \pm standard error) were compared between control and stressed cuttings at each date of measurement; $(*)$ : for each clone, significant differences $(P \leq 0.05)$ between control and stress conditions.
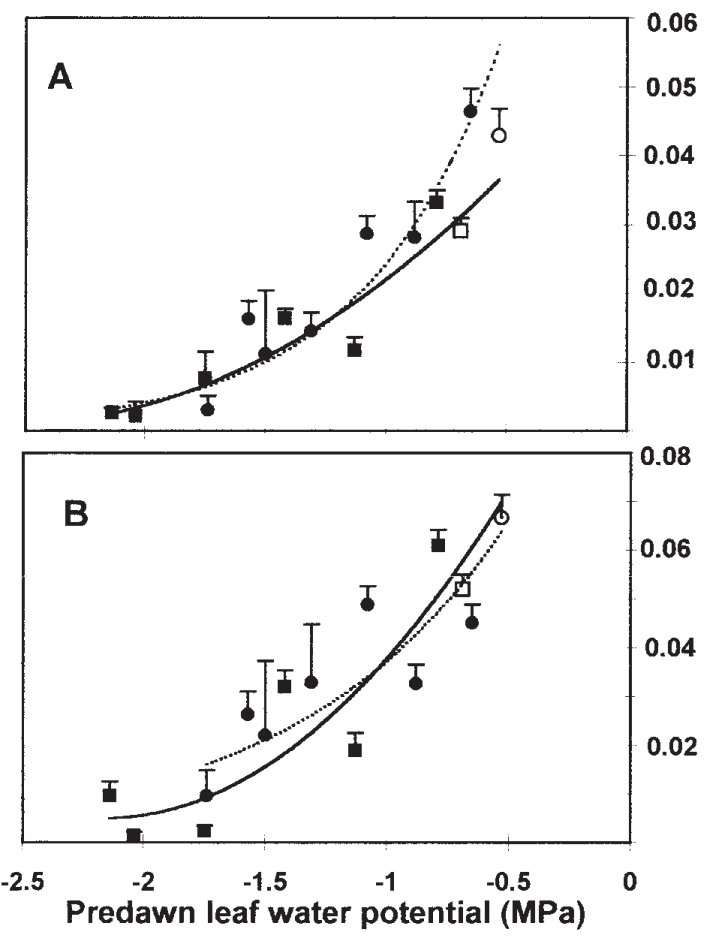

Figure 3. Relation and regression lines between predawn leaf water potential $\left(\Psi_{\mathrm{wp}}\right)$ and relative leaf number $(\mathrm{A})$ - and leaf growth rate (B), in control $(\square / \bigcirc)$ and stressed cuttings $(\square / 0)$ of Dorskamp ( - ) and Luisa Avanzo (-----). Otherwise as for figure 2. values, the relative rates of increase in number of leaves and leaf growth did not significantly differ between clones (figures $3 \mathrm{~A}$ and $B$ ).

The differences between clones, observed in well watered conditions, regarding the relative rates of increase in number of leaves and leaf growth, were not maintained under limiting water supply. Hence, the advantage of Luisa Avanzo under well watered conditions was counterbalanced by its higher susceptibility to water stress. This conclusion is corroborated by a greater decrease in total leaf area in response to stress for Luisa Avanzo than for Dorskamp ( $-450 \%$ and $-200 \%$, respectively), since the latter was exposed to the highest stress intensity throughout the experiment. Therefore, cuttings of these two clones constitute a relevant model for study of drought tolerance and for further research of markers associated with water stress resistance.

Acknowledgements: We thank Dr. E. Dreyer of the INRA Nancy for reviewing this manuscript. We thank G. Kahlem, Dr. M. Courtois, Dr. D. Morabito for their advised comments, and Dr. S. Hawkins for revising the English, and Rémi Bénardeau for his technical assistance.

\section{REFERENCES}

[1] Augé R.M., Duan X., Croker J.L., Witte W.T., Green C.D., Foliar dehydration tolerance of twelve deciduous tree species, J. Exp. Bot. 49 (1998) 753-759. 
[2] Barigah T.S., Saugier B., Mousseau M., Guittet J., Ceulemans R., Photosynthesis, leaf area and productivity of 5 poplar clones during their establishment year, Ann. Sci. For. 51 (1994) 613-625.

[3] Bennett J.M., Sullivan C.Y., Effect of water stress preconditioning on net photosynthetic rates of grain sorghum, Phothosynthetica 15 (1981) 330-337.

[4] Bisoffi S., Gullberg U., Poplar breeding and selection strategies, in: Stettler R.F., Bradshaw H.D. Jr., Heilman P.E., Hinckley T.M. (Eds.), Biology of Populus and its Implications for Management and Conservation, NRC-CNRC, Ottawa, 1996, pp. 139-158.

[5] Blake T.J., Sperry J.S., Tschaplinski T.J., Water relations, in: Stettler R.F., Bradshaw H.D. Jr., Heilman P.E., Hinckley T.M. (Eds.), Biology of Populus and its Implications for Management and Conservation, NRC-CNRC, Ottawa, 1996, pp. 401-422.

[6] Ceulemans R., Pontailler J.Y., Mau F., Guittet J., Leaf allometry in young poplar stands: reliability of leaf area index estimation, site and clone effects, Bioenergy 4 (1993) 315-321.

[7] Chen S., Wang S., Altman A., Hüttermann A., Genotypic variation in drought tolerance of poplar in relation to abscissic acid, Tree Physiology 17 (1997) 797-803.

[8] Dreyer E., Photosynthesis and drought in forest trees, in: Rennenberg H., Eschrich W., Ziegler H. (Eds.), Trees, Contributions to Modern Tree Physiology, Backhuys Publischers, Leiden, The Netherlands, 1997, pp. 215-238.

[9] Fordham R., Holgate M.E., Estimation of leaf area of tea (Camellia sinensis L.) from linear measurements, J. Hort. Sci. 47 (1972) 131-135.

[10] Gebre G.M., Kuhns M.R., Brandle J.R., Organic solute accumulation and dehydration tolerance in three water-stressed Populus deltoides clones, Tree Physiology 14 (1994) 575-587.

[11] Gebre G.M., Tschaplinski T.J., Tuskan G.A., Todd D.E., Clonal and seasonal differences in leaf osmotic potential and organic solutes of five hybrid clones grown under field conditions, Tree Physiology 18 (1998) 645-652.

[12] Groom P.K., Lamont B.B., Leaf morphology and life influence water relations of Hakea species on different soil substractes within southwestern Australia, Acta Oecologica 16 (1995) 609-620.
[13] Harvey H.P., Van den Driessche R., Nutrition, xylem cavitation and drought resistance in hybrid poplar, Tree Physiology 17 (1997) 647-654.

[14] Ibrahim L., Proe M.F., Cameron A.D., Main effect of nitrogen supply and drought stress upon whole-plant carbon allocation poplar, Can. J. For. Res. 27 (1997) 1413-1419.

[15] Levitt J., Responses of plants to environmental stresses, Vol. II, Water, Radiation, Salt, and Other Stresses, Academic Press, 1980.

[16] Liu Z., Dickmann D.I., Abscissic acid accumulation in leaves of two contrasting hybrid poplar clones affected by nitrogen fertilization plus cycling flooding and soil drying, Tree Physiology 11 (1992) 109-122.

[17] Meyer R.F. and Boyer J.S., Osmoregulation, solute distribution, and growth in soybean seedlings having low water potentials, Planta 151 (1981) 482-489.

[18] Pinon J., Valadon A., Comportement des cultivars de peupliers commercialisables dans l'Union européenne vis-à-vis de quelques parasites majeurs, Ann. Sci. For. 54 (1997) 19-38.

[19] Robison D.J., Raffa K.F., Productivity, drought tolerance and pest status of hybrid Populus: tree improvement and sylvicultural implications, Biomass and Bioenergy 14 (1998) $1-20$.

[20] Scholander P.F., Hammel H.T., Bradstreet E.D., Hemmingsen E.A., Sap pressure in vascular plants, Science 148 (1965) 339-346.

[21] Soulères G., Les milieux de la populiculture, Institut pour le développement Forestier, Paris, 1992.

[22] Stanton B.J., Villar M., Controlled reproduction of Populus, in: Stettler R.F., Bradshaw H.D. Jr., Heilman P.E., Hinckley T.M. (Eds.), Biology of Populus and its Implications for Management and Conservation, NRC-CNRC, Ottawa, 1996, pp. 113-138.

[23] Terrasson D., Populiculture: conditions d'utilisation de deux cultivars euraméricains «Luisa Avanzo» et «Cima», Info Tech CEMAGREF 69 (1988) 6.

[24] Tschaplinski T.J., Tuskan G.A., Gebre G.M., Todd D.E., Drought resistance of two hybrid Populus clones grown in a large-scale plantation, Tree Physiology 18 (1998) 653-658.

[25] Wargo P.M., Correlations of leaf area with length and width measurements of leaves of black oak, white oak, and sugar maple, USDA For. Serv. Res. Note NE-256, 1978. 